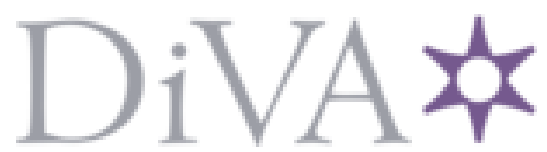

http://www.diva-portal.org

\title{
Postprint
}

This is the accepted version of a paper published in The journal of business \& industrial marketing. This paper has been peer-reviewed but does not include the final publisher proofcorrections or journal pagination.

Citation for the original published paper (version of record):

Löfberg, N., Åkesson, M. (2018)

Creating a service platform: how to co-create value in a remote service context

The journal of business \& industrial marketing, 33(6): 768-780

https://doi.org/10.1108/JBIM-10-2015-0202

Access to the published version may require subscription.

N.B. When citing this work, cite the original published paper.

Permanent link to this version:

http://urn.kb.se/resolve?urn=urn:nbn:se:kau:diva-7026o 


\section{Creating a service platform -How to co-create value in a remote service context}

\section{Abstract}

Purpose

The purpose of this article is to further develop the construct of service platform and to clarify the definition of service platform in an industrial context. To do so, an understanding of the foundations for service platforms, based on a service perspective, is created.

Design/Methodology/Approach

The study has adopted a qualitative case study approach and builds on in-depth interviews with remote service teams in two multinational firms: one in the food processing and packaging industry, and one in the pulp and paper industry.

Findings

The foundations for successful service platforms consist of modularising resources, integrations, and service processes to create value propositions. The value propositions could result in variations of a service or in variations of different services. When defining the concept service platform, the perspective of service needs to be made evident; therefore, we define service platform as: value proposition(s) consisting of a modular structure that invites to and facilitates value co-creation between resources, through integration opportunities in a continuous service process.

Research limitations/implications

The results are based on the perspective of two suppliers in similar industries; only remote services were studied. Firms from different types of industries and other types of services could add to the research on service modularity according to a service perspective. Moreover, information about customers and other actors' involvement on the platform was gathered from the firms studied, no customers or other actors were interviewed.

Practical implications

This study shows the importance of a firm involving itself in the value creation of the customer; that is, focusing on value co-creation. This implies a close cooperation between the manufacturer and its customer - not only at a given point in time, but over a longer period of cooperation. Through the different types of modules building up the service platform, value co-creation can take place in various ways.

Originality/value

This study offers original empirical contributions on platforms from a service perspective. The study contributes to servitisation, service modularity, and service (dominant) logic research by developing an understanding of the foundations for service platforms based on a service perspective. It also contributes to platform research more specifically by developing a definition of service platform in an industrial context.

Keywords: Service platform, Remote service, Service modularity, Value co-creation, Service logic 


\section{Introduction}

Servitisation is associated with an increased focus on services that are more advanced than those traditionally offered by manufacturing firms. The shift from selling products to services is facilitated by advancements in technology (Wünderlich et al., 2013) and IT has become an important element in many services. With the emergence of the Internet of things (IoT) (Mazhelis et al., 2013; Barnaghi et al., 2012), the complexity of services has increased further.

The IoT is characterised by products that are able to transmit and receive information in real time (Ostrom et al., 2010). These technological advances have led to the creation of remote services, which can be defined as service types provided via a technology-mediated production process in which the provider can actively access the service object over long distances (Schumann et al., 2012). By providing real-time data about the installed base, companies can avoid risks for the customer such as non-availability and suboptimal product performance (Grubic, 2014).

Offering remote services implies new ways of working with customers (Grubic, 2014) and many firms struggle to convince customers of the benefits of such services (Kuschel and Ljungberg, 2004; Westergren 2011). Being used to selling products, manufacturers see their remote services as technological solutions. However, in accordance with Grubic (2014) and Brax and Jonsson (2009), we argue that manufacturing firms can benefit and capture value from their remote services to a greater extent if they are approached from a service platform perspective.

The traditional view of service platform has been inherited from production research; consequently, definitions of service platforms have been primarily based on productisation of services (e.g., Pekkarinen and Ulkuniemi, 2008; Bask et al., 2010; Voss and Hsuan, 2009). Only recently has the construct of service platform been discussed from a service perspective (e.g. Lusch and Nambisan, 2015; Saarikko, 2016). According to Lusch and Nambisan (2015), the prime goal of service platforms is to function as a venue for innovative, effective, and efficient service exchange. Therefore, service platforms can be seen as serving actors in their day-to-day work. Characterised by the opportunities for ongoing resource integration between the firm and its customers, the concept is similar to what Grönroos and Gummerus (2014) termed a "platform for value co-creation".

Building on this service perspective, a remote service can be viewed as a service platform that gives customers and service providers an opportunity to create value in use (Grönroos, 2011a). The value-in-use perspective implies that value is not embedded in an offering, but is created by the customer during value creating processes; in other words, a product or service would be useless if it was not used (Normann and Ramírez, 1993; Ravald and Grönroos, 1996; Wikström, 1996; Vargo and Lusch, 2004; Grönroos, 2006, 2008). Therefore, value is always created by the customers themselves, but the supplier can offer support (Storbacka and Lehtinen, 2001) and, consequently, co-create value (Grönroos, 2008). Value co-creation has been stated as an important area for future research regarding service platforms (Pekkarinen and Ulkuniemi, 2008).

Value co-creation is naturally complex, and since offering advanced services (such as remote services) is facilitated by a value co-creation perspective within the company (Löfberg, 2014), we argue that the service platform needs to be built accordingly and, consequently, the concept of service platform needs to be defined accordingly too. Companies need to handle the complexity of advanced services rather than trying to reduce it (cf. Eloranta and Turunen, 2016), something which is not evident in the current definitions of the concept. Therefore, to build the construct of service platform, we argue that a service perspective is necessary.

The purpose of the present article is to further develop the construct of service platform and to clarify the definition of service platform in an industrial context. To do so, an understanding of the foundations for service platforms, will be created. Inspired by Lusch and Nambisan (2015) and Grönroos and Gummerus (2014), we apply a service perspective (e.g., Grönroos, 2008, 2011a), when 
developing the construct of service platform. The empirical context is the remote service teams of two multinational industrial firms.

This article makes several contributions. First, it helps fill the gap in the literature caused by the lack of empirical evidence on platforms from a service perspective (Eloranta and Turunen, 2016). Second, it contributes to platform research by developing the construct of service platform. Third, the understanding of the foundations for service platforms based on a service perspective will contribute to servitisation, service modularity, and service (dominant) logic research.

The remainder of this paper is structured as follows. The literature review presents service platforms, a service perspective on platforms, and remote service as service platforms. We then explain the qualitative case study approach, present the case companies, and explain the data collection and interpretation. The findings illustrate the remote services' content at the case firms. In the discussion the following modules are found to be important parts of a service platform: resources, integrations, service processes, and value propositions. Finally, we present the conclusions of the study, managerial implications, and suggestions for future research.

\section{Service platforms}

A platform is traditionally seen as a design for products, services, and infrastructure facilitating users' interactions (Eisenmann et al., 2006). Moreover, platforms are used to realise mass customisation, and the heart of a platform is the organisation of the components and interfaces that make up the product or service (Mikkola, 2007). As such, platforms were initially seen as a way to ensure that internal structures did not get overly complex when a firm's offerings increased substantially (Sawhney, 1989). The idea was to offer products and services that could easily be modified on the platform (Meyer, Tertzakian, and Utterback, 1997; Sawhney, 1998; Wheelwright and Clark, 1992).

The history of the platform literature as being based on productisation of services is inherited in the construct of 'service platform' (see, e.g., Bask et al., 2010; Voss and Hsuan, 2009). It divides the platforms into types of modules that are created by the company and for the customer, rather than cocreated by the two. This is evident in definitions such as the one by Pekkarinen and Ulkuniemi (2008), who defined service platform as a way for firms to develop, organise, and provide modularised service offerings. They identified three levels of service modularity: services, processes, and organisation. The service modules are considered to be visible to the customers, whereas the process and organisation modules are argued to be intra-organisational. This is also consistent with an idea that has come to be central in the servitisation literature; that is, to understand platforms as modular structures in order to improve customer orientation but avoid organisational complexity (Eloranta and Turunen, 2016).

From a service perspective, Chesbrough (2011) contributed to platform research by illustrating that service efficiency can be improved by dividing the supply side into a back-end side and a front-end side. The back end consists of standardised internal processes of the infrastructure needed to form, support, and deliver services. In order to provide the required flexibility needed to cope with various environments and customer preferences, the front end is adaptable. Chesbrough (2011) advised firms to develop the platform for others to connect and build upon, and to invite customers to co-create value on the platform.

Based on a service perspective, Lusch and Nambisan (2015:162) defined a service platform as: "A modular structure that consists of tangible and intangible components (resources) and facilitates the interaction of actors and resources (or resource bundles)." The components consist of knowledge and skills in the form of tangible or intangible components that can easily be used with different product 
forms and types. Applying this view on service platforms means that it can be used both to create completely different value propositions and also to offer alternations of a core value proposition.

Based on a similar idea, Smedlund (2012) elaborated on the service platform concept when describing how value is co-created in different ways, depending on the capabilities of the actors on the platform. He emphasised the importance of the business logic used in the business models of a service platform, thereby contributing to the construct of service platform from a service perspective.

Some servitisation researchers have also applied a view of service platforms as value-creating processes, focusing either on the customers (Carlborg and Kindström, 2014) or on the customers' perceived value (Rahikka et al., 2011). Brax and Jonsson (2009) and Kindström and Kowalkowski (2009) have contributed to the understanding of service platforms by focusing on practical implication through service delivery platforms. Brax and Jonsson (2009) emphasised the need for firms to understand their customers' needs and understand their business processes, as well as to evaluate offerings and competences from the customers' perspective. This indicates a need for co-created service processes as part of the service platform. Despite being discussed in service contexts, the construct of service platform requires further development in order to address a service perspective and not only services as an output of production.

\section{A service perspective on platforms}

Mele (2009) emphasised that the core mechanism of value co-creation is the integration of resources of several actors. According to a service perspective, resources can include people, systems, infrastructures, and information (e.g., Grönroos, 2006). Knowledge and skills are central resources (Vargo and Lusch, 2004; 2008a; Lusch and Nambisan, 2015) and they have been emphasised as an important ingredient of a platform for service innovation (Windahl and Lakemond, 2006; Lusch and Nambisan, 2015).

Value co-creation therefore rely on resource integration. Firms will be able to co-create value by adding to the customer's resources or influence its process such that it can utilise the available resources more efficiently and effectively (Payne et al., 2008). To achieve that, integration activities that build on dialogue between firm and customer rather than one-way communication, is necessary in order to create truly close relationships with customers (Ballantyne and Varey, 2006). Therefore, there is a mutual interest in involving the customer in the service process and it is understood that the customer wants to participate in order to learn more and gain experience (Kuschel and Ljungberg, 2004). Consequently, the ongoing dialogue is a process of joint learning (Ballantyne, 2004).

Viewing service as a process (e.g., Edvardsson et al., 2005; Lovelock and Gummesson, 2004) moves the focus away from units of outputs, such as material or immaterial goods or services (Vargo and Lusch, 2008b), to service as a perspective. This view supports the co-creation of value and may consist of procedures, tasks, mechanisms, activities and interactions (Payne et al., 2008). Moreover, it is similar to the view of Grönroos $(2008,2011 b)$, who claimed that service is all about supporting customers with a set of resources and interactive processes. Hence, a service business would assume much wider responsibility for a customer's everyday practices when it supports them with goods and service activities in order to enable the customer to create value from the core process. Consequently, the way in which the customers are supported through the service process needs to be clearly articulated in the value proposition.

Leaning on Lusch and Nambisan's (2015) research, Saarrikko (2016) pointed out that the notion of value proposition is the core of a platform. Value propositions are composed of various processes, resources and interactions, offered to customers to be integrated into their value-creation process in 
order to create value-in-use (Grönroos and Voima, 2013; Vargo and Lusch, 2004, 2008a; Vargo et al., 2014). As such, these value propositions are used to communicate what is expected of a service. More recently, value propositions have been described as an invitation to engage with a firm - and potentially other actors - during the co-creation of value (Vargo and Lusch, 2004; Chandler and Lusch, 2015). Skålén et al. (2015:154) define value propositions as "(co-)created promises of customer value that are backed up by plans regarding how resources can be efficiently integrated through practices."

\section{Remote services as service platforms}

Brax and Jonsson (2009) found that most remote service projects were approached as technical projects rather than business development projects, leaving the value propositions unarticulated. That makes it difficult for many firms to convince their customers of the benefits (c.f. Küssel et al. 2000), which is further complicated by the scepticism regarding remote service technology among many customers (Kuschel and Ljungberg 2004; Westergren 2011).

Manufacturers must realise that the technology per se does not add value to customers (Oliva and Kallenberg, 2003). Firms must find new ways of working together with customers and therefore remote services include changes in the mindsets of employees (Grubic, 2014). If managed correctly, remote services can imply benefits for the customer, such as minimisation of downtime (Küssel et al., 2000; Jonsson et al., 2008) and transfer of risks to the manufacturer (Brax and Jonsson, 2009; Gremyr et al., 2010). For the manufacturer, remote services offer benefits such as new service development and cost reduction (Laine et al., 2010; Brax and Jonsson, 2009). We argue that viewing remote services as a service platform will help manufacturing firms to create benefits. In order to do so, the remote service needs to be viewed as a co-creation project (e.g., Kuschel and Ljungberg, 2004; Grubic, 2014).

\section{Method}

In order to further develop the construct of service platform and to clarify the definition of service platform in an industrial context, we opted for a qualitative case study approach (e.g., Eisenhardt, 1989; Merriam, 1998). This approach is suitable for exploratory research (Eisenhardt and Graebner, 2007; Yin, 2003), and was selected since service platforms from a service perspective have only been sparsely researched. We chose remote services as our empirical context partly due to the integration possibilities they enable and partly because, when applying a service perspective mind-set on remote services, it is possible to view them as service platforms. As such, a remote service can be seen to complement the team of the customer and the manufacturer as a platform for sharing data and other kinds of resources that can be used to co-create value, such as minimising downtime for the customer and maximising service development opportunities for the manufacturer. Furthermore, remote services have only attracted scant research interest, specifically in terms of service platforms. Being a complex and contextbound research subject, the case study approach helped gaining a detailed understanding of remote services as service platforms (e.g., Eisenhardt, 1989; Merriam, 1998, Miles and Huberman, 1994).

The study was conducted at two firms - one in the food processing and packaging industry (subsequently referred to as the 'packaging firm'), and one firm in the pulp and paper industry (subsequently referred to as the 'pulp and paper firm'). The units of analysis have been the remote service at the firms. To be selected for the study, the companies had to:

1. Be manufacturing firms on a B2B market

2. Offer remote service(s)

3. Have service departments that were primarily service-oriented. 
The pulp and paper firm is also a multinational company, with more than 12,000 employees worldwide. This firm offers technologies, automation and services to the pulp, paper and energy industries. The remote service studied has been offered for approximately a year and is still under development. It supports the paper machines offered by the firm.

The packaging firm is a large multinational firm with more than 23,000 employees located in over 85 countries. This firm offers complete solutions in processing and packaging different types of food. Its remote services support the installed base of packaging machines by offering, for instance, condition monitoring feedback, performance feedback, and 24/7 remote support. The company has been offering remote services for about a decade.

\section{Data collection and interpretation}

The study builds on in-depth interviews and documentation in terms of customer presentations, and we also used a customer survey for clarification when needed. The documentation was mainly used to gain insights into how the firms present their remote services to their customers. In total, we interviewed seven employees and the interviews lasted between one and three hours. All interviews were conducted face-to-face at the respective companies local service departments in Sweden. At the pulp and paper firm, interviews were conducted with all four employees (a marketing professional, a sales manager, a senior process engineer, and a technician) working with the remote service at the company's Swedish service department. At the packaging firm, interviews were conducted with three participants (the remote service manager, the former remote service manager, and the product manager) who are either currently working or have previously worked with remote services. The three interviewees were also involved in the development of the services.

In order to help us gain a deep understanding of the services, the interview guide was semistructured and included a variety of areas, including the remote service development process, the marketing of the remote service, the remote service process, and relationships with customers. During one of the interviews, the guide was adapted to suit the interviewees' special competencies and tasks; that is, the marketing of the service. The interviews were recorded and transcribed, then analysed using Nvivo. The interviews were conducted in late 2015 and early 2016.

Codes and categories (see, for instance, Miles and Huberman, 1994) were created in order to provide an understanding of remote service as a service platform. Each case was first analysed individually and then compared to each other (Eisenhardt, 1989; Yin, 2009). This process was also influenced by the combination of existing literature (on service platforms and service (dominant) logic) with the author's interpretations while the empirical data was being analysed. This means data was grouped and regrouped until themes and patterns emerged. This abductive research process was described by Dubois and Gadde $(2002,2014)$ and is referred to as systematic combining. The process continuously related data back to selected theory as the analysis progressed.

\section{Findings}

\section{The process optimisation service at the pulp and paper firm}

The pulp and paper firm offers a process optimisation service that is performed together with the customer in order to optimise the production process of a delivered paper machine. In this way, customer value is created in different ways. The risk of downtime is decreased since the machine is producing optimally, continuous support is given to new or small customers, and when there is a problem it can be identified remotely and the right expertise and equipment can be sent to the customer's 
site. Moreover, the customer can improve its own capabilities by learning about process optimisation and, after some years, continue with an optimised production process without buying the remote service.

For the firm itself, the remote service creates value in several ways. First, the remote service influences the branding, as the company wants to be seen as technology-leading advisors and experts, and not primarily as a supplier of machines. Secondly, employees do not need to travel as much when some issues can be addressed remotely, which means it is easier to retain competent staff when their job includes less travelling. When visits at customer site are necessary, the remote service means the correct expertise can be sent directly because a problem can be identified from a distance. Consequently, travel costs decrease. Finally, the remote service facilitates the creation of good customer relationships, as current data and related analyses serve as a base for continuous discussions with the customer. In turn, this makes it harder for the customer to switch suppliers. The senior process engineer described this close collaboration as follows:

"And I don't know about you, but I become friends with someone when we've worked together and done something, solved a problem or whatever [...] it improves the contact between us. It creates a shared success, in a way. 'We had a problem, you and I, and we solved it'."

\section{The service process of the process optimisation service}

The process optimisation service is delivered in customised variations and, essentially, is built up by the following process modules (see Table 1): data transmission, data analysis, report to customer, action plan, continuous discussions, customer visit, and follow-up. These are service process modules that, in different combinations, create variations of the core value proposition of this service offering.

In the data transmission module, data is transmitted from the customer to the firm through a technical solution made by a partner firm. The data itself is owned by the customer and, together with information, it constitutes the resources that the customer adds to the initial stages of the service process. The following module, data analysis, is the most important part of the service process. The suppliers have the ability to combine software with staff knowledge of the machine, resulting in important information that could prevent breakdowns or increase the efficiency of the machine. In addition, the software also helps to analyse the performance of the machine at different times. The senior process engineer at the pulp and paper firm described this as follows:

"Then we download data from this machine and then we analyse [...] how the machine has been doing for eight hours and then we write a report about it. This is how the machine worked over the eight-hour period. And when we've done that many, many, many times, we can compare. This is how it worked in March and this is how it worked in April and so on."

Moreover, the suppliers compile data from a large installed base, and the accumulated knowledge of other customers' machines becomes a benchmarking opportunity.

The recommended measures resulting from data analysis are reported to the customer. In order to present the measures to the customer, and to discuss possible actions to take, different templates are used and information becomes an important resource, as does the employees' knowledge.

The actions to be taken are then summarised in an action plan, which is formulated jointly with the customer during visits, and by means of video conferences and/or phone calls. The senior process engineer explained: "We are at the office and the customer is at their place. Then we share information and try to solve these problems."

The action plan is followed by continuous discussions between the firm and the customer. Video conferences are used to keep in contact with the customer on a regular basis and they are complemented with customer visits. Except for regular meetings, this module could also include, for example, trimming of the machine or job training of customer staff to improve the customer's process. 
The final module of the process optimisation service is the follow-up, where the actions taken are evaluated and the performance of the machine and current customer challenges are discussed at a meeting.

$<$ Insert Table 1 about here. $>$

\section{The condition monitoring feedback service and the performance feedback service at the packaging firm}

The packaging firm offers multiple remote services, in order to optimise the processing and packaging solutions it sells to customers. Two of these services are here used to illustrate how modules on a service platform can result in different value propositions (i.e. two different service offerings), or in variations of these value propositions. The modules illustrated in Table 2 build up a condition monitoring feedback service and a performance feedback service.

The customer value creation that can be achieved by the services is in many ways similar to the pulp and paper firm's: minimising risk of downtime, continuous support and training, faster help in emergency situations, services when needed rather than at specified times, and possibility to detect abnormal conditions.

The value captured for the firm can be enhancement of the performance of the firm's machines through continuous improvements possibilities. From the gathered data the firm receives knowledge about, for instance, whether the same abnormal conditions occur at several customers' machines, which could imply a need for an improvement in their machines. Other value capture possibilities are saving costs from sending the right expertise and equipment to the customer's site as well as detecting various potential problems enabled by additional service sales.

For example, by being the party that detects an upcoming breakage, the customer usually buys the service offering that will solve the breakage. This creates value for both parties: the firm gets to sell additional services, and the customer saves money by presenting the problem before the issue actually occurs. The remote service manager described such a situation: "This sensor is broken; do you want me to change it for you? And then you change to a new one. The customer goes home and says, 'That's a nice agreement, they actually helped me manage my site and for that reason I want to continue working with them [the Packaging firm]'."

\section{Example of a service process at the packaging firm}

Variations of the following process modules build up the condition monitoring feedback service and the performance feedback service (see Table 2): data transmission, awareness of abnormal conditions, report to customer, service offering, maintenance on site, education, and upgrades. These are service process modules that, in different combinations, create different service offerings, or value propositions.

In the data transmission module, the customer-owned data is transmitted automatically from customer to the firm through secure and reliable Internet access. The technical solution is provided by a partner firm and the inspection is automatic. After that, data analyses are performed in order to detect any abnormal conditions. Resources within this module consist of firm employees with deep knowledge about the installed base and analysis competences, certain software to perform the analyses, and a database of data from other customers' machines used for benchmarking. The inspection is automatic unless there are any detections of an abnormal condition that requires immediate action. An immediate phone contact between expert and customer then takes place. 
The results of the analyses are then being reported to the customer. The resources consist of firm employees with the right knowledge, templates for written reports, and information consisting of elements such as performance and/or production reports. Written reports as well as information transmission from firm to customer take place. In the next module, discussions about choosing a suitable action plan to help enhance performance of a machine become central.

Then, maintenance on customer's site is performed by a firm employee who has expert knowledge about the machine. Data from the customer's machine and data from benchmarking machines are used as resources. At this stage manual inspections and discussions between firm and customer take place.

Many customers experience the need to educate their employees. Often the operators who run the machines are "coming and going" and there is a continuous need for education. The packaging firm offers educational services in the form of downloadable manuals and training sessions. Finally, upgrades to improve customer's machines are continuously needed.

$<$ Insert Table 2 about here. $>$

\section{Discussion}

Leaning on Lusch and Nambisan's (2015) view of a service platform as a modular structure consisting of resources that facilitates interaction, and following Grönroos' (2011b) view that the interactive process constituting a service offering consists of several sub-processes and resources, we add to the literature on service platform from a service perspective (see e.g., Grönroos, 2008; Grönroos and Gummerus, 2014). Our data analysis revealed the foundations for successful service platforms; namely, modularising resources, integrations, and service processes to create value propositions. In line with Lusch and Nambisan's (2015) view, we are able to illustrate empirical data on how modules on a service platform can be used both to create completely different value propositions, but also to offer alternations of a core value proposition.

\section{Resources}

To offer the remote services studied, resources from the supplier, the customer, and other actors (such as partner firms) were involved. As pointed out by Mele (2009), the integration of resources is a core mechanism of value co-creation and is therefore a central part of a service platform. As illustrated in Table 1 and 2, different types of resources are integrated at different modules of the service process. For example, in order to analyse the data, the resources added by the studied firms include their databases of data collected from the installed base, and their employees' specialised knowledge. The sales manager at the pulp and paper firm explained this as follows: "About data, it's data that comes out, it is, but it's not the data per se [that is the most important part of the offering], it's the interpretation of that data, I would say."

As such, the data transmitted from the customer only has potential value, but it becomes valuable when an expert interprets it. Hence it is the knowledge and skills of the employee that seem to be the prominent resource, as pointed out by Lusch and Nambisan (2015). This example of resource integration will result in value co-creation, as value is created both for the customer (for example, knowledge about the production status of its machine) and the manufacturing firm (such as obtaining feedback for R\&D that enables learning and knowledge creation). In this way, both the firm's and the customer's competitiveness is improved by the remote service. 


\section{Integrations}

To co-create value, resource integration between actors on the service platform becomes central. It is through integrations that the manufacturing firm and the customer can influence each other's processes to find the most efficient and effective way to use available resources (Payne et al., 2008). Consequently, continuous integrations are the key to creating truly close relationships with customers. A manager at the packaging firm explained: "The salesman is there [...] very much, very often, listen, listen, listen, talk, talk, talk, talk in order to understand the customer's needs." This close relationship with the customer, consisting of two-way communication, is in line with Grönroos (2006) and Ballantyne and Varey (2006). It implies the need for a very deep knowledge of the customers and their situation in order to be able to offer the most suitable value proposition for each customer.

An example of the consequences of this was evident at the pulp and paper firm, where a manager explained that if the customers really paid attention during the integration activities of the remote service, they would no longer need the service after a few years. Some might see this as a problem, in that teaching the customers to serve themselves might mean that they will not have to purchase the service at some point in the future. However, the firm considers the trust and collaboration that this creates to be more valuable for the firm-customer relationship.

Not all customers are interested in investing in such a close relationship (Rust and Thompson, 2006), which would leave the customers as the sole value creators rather than admitting the service provider into processes and enabling them to co-create value (Grönroos, 2011b). As the technician at the pulp and paper firm explained: "An important part is security; none of our customers wants information about them to be public, they carefully keep their secrets." This scepticism against remote services among customers was also noted by Kuschel and Ljungberg (2004) and Westergren (2011). Security issues might be connected to trust, since a lack of trust means no further dialogue (Ballantyne and Varey, 2006).

An example of this is the data transmission in all remote services studied here. In the data transmission module, the integrations consisted of gaining access to the data. Whether or not the supplier gained access to the customer's machine was dependent on factors including culture. Some customers do not want to feel monitored, and therefore protected their data as a trade secret; however, others see the opportunities in the support they can get and in comparing their machines to similar ones in order to know their performance levels.

Some customers took their own integration initiatives, which would not have been possible without a service platform such as the remote service. In line with Ballantyne and Varey (2006) and Grönroos (2011b), this illustrates that initiatives can be derived from actors other than just the service provider. It also illustrates that our case firm has been successful in making the resources and capabilities on the service platform visible for the actors of the network. This is something that was suggested as important by Eloranta and Turunen (2016).

\section{Service process}

Resource and integration modules build up a service process that is co-created on the service platform. This way of discussing modularisation of processes rather than objects adds to the findings of Carlborg and Kindström (2014). In order to build the service process of a remote service, integration between different resources is central. This concept is in line with Grönroos (2011a), who argued that a service process is a combined and coordinated interactive process. 
To co-create value with the customer in the service process, the packaging firm worked in close collaboration with its customers, which helped it take a large responsibility for its customers' everyday practices and processes, as advocated by Grönroos (2011b). The remote service manager at the packaging firm explained this process as follows:

"We monitor certain conditions on the customer's plant. Take, for instance, the separator, a large metal globe that is put into dangerous rotation. It weighs a couple of hundred kilos and if it is not completely symmetrical, it starts rotating. And if it is being released, you have half a ton that takes off. It goes through quite a few walls before it stops. Therefore, we monitor the separators all the time, and when we observe something abnormal we call the customer and we are usually happy to offer them the service needed through maintenance on their plant."

Through close collaboration, the packaging firm is able to, for example, detect any abnormal conditions and offer suitable service to help enhance the performance of the customer's machine. However, the remote service manager did express that there were customers that did not give them the access they would have needed in order to provide successful support of their customers' processes.

In line with Kuschel and Ljungberg (2004), this illustrates the mutual need for customers to be willing to participate in order to co-create successful value on the service platform. According to the product manager at the packaging firm, the lack of customers' willingness to participate was often connected to Internet security, since the customers were afraid of getting viruses into their systems. In order to offer successful remote services, it is necessary to overcome this challenge of being able to cocreate safe and secure service processes so that the value propositions can be fulfilled.

\section{Value propositions}

The value propositions are made up of combinations of service process modules. It was clear from the empirical data that various modules of a service do differ between customers due to varying preferences; for example, which data the supplier gets access to, what data analyses to perform, and how many visits to the customer site to include. This was clearly explained by the product manager at the packaging firm:

"In reality, the service consists of a number of standards. The customer can't see that, but it does. For instance, remote support consists of 20 chapters; the first chapter might be about the connection, the second about how often to connect, and the third about response times, and so on. But the service must be completely tailored to each customer with regard to his/her needs and requirements - some chapters might be removed, for instance."

The question of what service process modules to include in a certain value proposition is determined through customer-firm discussions, also continuously on the service platform. Therefore, value propositions can be the result of integration between the parties as a co-created agreement (c.f. Payne et al., 2008). Consequently, it is necessary to know what customers value and how value propositions could be designed in order to align with the customers' expectations. However, this could be a real challenge for a manufacturing firm that is not used to co-creating value, according to the product manager at the packaging firm: "[...] but still, the major challenge with all remote services is really understanding the customer's problem." This quote implies the difficulties of creating a value proposition that both suits the customer's needs (in line with Westerlund, 2011), and also truly addresses the customer's challenges and problems. In order to be able to suggest the right type of value proposition, the packaging firm, in particular, spent a lot of time understanding its customers' processes, as explained by the product manager: 
"I would argue that we need to understand the customer's activities and processes 100 percent. We can't just say to the customer, 'Would you like to buy this remote service?' unless we understand what he/she really wants."

\section{Conclusions}

Service platforms often constitute the foundation for advanced service offerings, such as remote services. Selling advanced services is often consistent with a number of challenges (Löfberg, 2014; Grubic, 2014) and remote services are no exception (Kuschel and Ljungberg, 2004; Westergren, 2011). Previous research (Löfberg, 2014) has shown that challenges related to advanced services can be addressed and overcome by a value co-creation perspective; thereby stressing the importance of a service perspective on service platforms.

However, practitioners and researchers have mostly continued to view service platforms from a traditional goods perspective, focusing on technical solutions rather than a platform that gives actors an opportunity to co-create value. Inspired by Lusch and Nambisan (2015) and Grönroos and Gummerus (2014), we apply a service perspective in order to further develop the construct of service platform. Moreover, research on service platforms has provided few empirical articles on the modules that make up a successful service platform. To add to this research gap, this study used empirical data from two business-to-business firms' remote services initiatives.

\section{Theoretical contribution}

By combining empirical findings with central aspects from service (dominant) logic literature, we found the service platform modules of resources, integration, and service processes. The modules imply that they can be combined to result in various value propositions or alternations of core value propositions (see Figure 1).

- Insert Figure 1 about here -

Identifying these foundations for successful service platforms has certain implications. First, the prominent resources are knowledge and skills (Vargo and Lusch 2004; Lusch and Nambisan, 2015). As these resources are offered and available on the platform, the firm and the customer can use them to cocreate value. Consequently, manufacturers must realise that the technology per se does not add value to customers, a shortcoming stressed by Oliva and Kallenberg (2003). Rather, the technical solution that constitutes the platform will facilitate value co-creation (cf. Grönroos and Gummerus, 2014). Consequently, the service platform construct must include resource integration, and resources central to services, such as knowledge and skills, should be prominent.

Second, integration becomes a central foundation when developing the construct of service platform. Integration opportunities are necessary in order to create close customer relationships. The packaging firm emphasised this as the most important part in selling remote services. However, doing so could be a challenge because the firm needs to manage different types of customers; not all customers want to participate in an ongoing interactive process (Rust and Thompson, 2006; Kuschel and Ljungberg, 2004), whereas others often take integration initiatives on the platform. Our study shows that the firm that engaged in the most integration activities with customers had the most successful remote service offerings. The firm with less focus on integration activities struggled more to sell the service. Therefore, integrations are central to the construct of service platform and, through modularity, can be adapted to suit different types of customers. 
Third, as viewed in Figure 1, modules of resources and integrations build up the service process, which needs to be seen as modules of processes rather than objects (cf. Carlborg and Kindström, 2014). Through the remote service, the firm takes a larger responsibility for the customer's everyday practices, and the service process needs to be built on an ongoing integration process in order for value co-creation to take place (cf. Grönroos and Gummerus, 2014). In contrast to Pekkarinen and Ulkuniemi (2008), who argued that only the service modules are visible to customers and not process and organisational modules, our study emphasises the visibility of all modules on the service platform. Consequently, an open service process focused on resource integration are central to the construct of service platform.

Finally, as previous research has already pointed out, the notion of value proposition is the core of a service platform (Saarrikko, 2016). By creating a remote service as a service platform, we argue that the modules constituting the foundations can be useful for achieving successful value propositions to fit various customers' needs, and hence to deal with complexity. In doing so, the firm can influence the customer's processes in such a way that the available resources are more efficiently and effectively used (Payne et al., 2008).

To conclude, the creation of service platforms based on a service perspective will help firms to handle the complexity in advanced service offerings, such as remote services (cf. Eloranta and Turunen, 2016). Building on modules that are based on value co-creation rather than objects involves both the firm and the customer (as compared to previous research, e.g., Bask et al., 2010; Voss and Hsuan, 2009; Pekkarinen and Ulkuniemi, 2008). Doing this will shape the close relationships and the cooperation needed to create successful service platforms.

Based on a service perspective, Lusch and Nambisan (2015:162) defined service platform as: "A modular structure that consists of tangible and intangible components (resources) and facilitates the interaction of actors and resources (or resource bundles)." We argue that this definition lacks the central concepts that differentiates a service platform from a product platform. When defining the concept service platform, the perspective of service needs to be made evident; therefore, we define service platform as: value proposition(s) consisting of a modular structure that invites to and facilitates value co-creation between resources, through integration opportunities in a continuous service process.

\section{Managerial implications}

Creating an advanced service, such as a remote service, as a service platform, enables managers to focus on the aspects that are important to develop, and to deliver these types of services successfully. Basically, the firm needs to involve itself in the value creation of the customer; that is, to focus on value co-creation. Through the different types of modules that build up the service platform, value co-creation takes place in various ways.

First, managers must understand that what creates value is not the technology per se, but what they are able to do with it. Focus should be on what competences and skills that are available in the company. However, previous research (Brax and Jonsson, 2009) found that most remote service projects were approached as technical projects rather than business development projects, leaving the value propositions unarticulated.

Second, firms need to continuously interact with customers to learn about their activities and processes. Our empirical data shows that in order to offer suitable value propositions, it is necessary to spend much more time and effort on getting to know the customers than product-oriented firms normally expend. This was shown to be especially important if a firm's offering is more expensive than its competitors', since the firm then needs to be able to argue the benefits of the service and support the value proposition. Moreover, the remote service per se offered the manufacturing firm integration opportunities, since it gave the sales force actual facts and figures about the customers' processes to utilise for discussion on a regular basis. It also helped the manufacturing firm achieve a holistic view 
of the customers' processes, since it implies close cooperation between the manufacturer and its customers, not only at a given point in time, but over a longer period of cooperation. However, taken together, the focus on knowledge and skills, as well as the close relationships created with customers due to intense integrations, could lead to firms being more dependent on employees that are not easy to replace.

Finally, through continuous integration activities with the customer, service process modules that create value for both the customer and the firm can be developed. An engineer at the packaging firm explained that he was analysing data from a remote service when he realised that an important bolt was about to separate from the packaging machine. By noticing this in time, he was able to solve the problem before the bolt actually failed, thereby preventing a major breakdown that would have been very expensive for the customer. In addition, the engineer was able to ensure that a stronger bolt would be used in future machines. Hence, the remote service was also able to lead to service improvements for the manufacturer, which ensures that better value-in-use can be promised in future value propositions.

\section{Limitations and future research}

The case study approach used in this study limits the statistical generalizability of the findings however, conceptual development rather than statistical generalization is the aim of case study research. Another limitation of this study is that it has focused on remote services in two manufacturing firms in similar industries. For future research, other types of services and firms from different types of industries could add to the research on service platforms according to a service perspective. This study also emphasises the importance of involving customers and other actors in the service process and argues that these actors build up resources as well as integration activities. However, the empirical data is limited to the supplier perspective, and future research could explore the topic from other actors' perspectives. For instance, the role of the customer and how customers integrate resources could be investigated. It may also be fruitful to discuss how the concept of trust affects resource integration and, as such, the opportunities for value co-creation.

\section{References}

Ballantyne, D. (2004), "Dialogue and its role in the development of relationship-specific knowledge", Journal of Business and Industrial Marketing, Vol. 19 No. 2, pp. 114-123.

Ballantyne, D. and Varey, R. J. (2006), "Creating value-in-use through marketing interaction: The exchange logic of relating, communicating and knowing", Marketing Theory, Vol. 6 No. 3, pp. 335348.

Barnaghi, P., Wang, W., Henson, C., and Taylor, K. (2012), "Semantics for the internet of things: Early progress and back to the future", International Journal on Semantic Web and Information Systems, Vol. 8 No.1, pp. 1-21.

Bask, A., Lipponen, M., Rajahonka, M. and Tinnilä, M. (2010), "The concept of modularity: Diffusion from manufacturing to service production", Journal of Manufacturing Technology Management, Vol. 21 No. 3, pp. 355-375. 
Brax, S.S. and Jonsson, K. (2009), "Developing integrated solution offerings for remote diagnostic: A comparative case study of two manufacturers", International Journal of Operations \& Production Management, Vol. 29 No. 5, pp. 539-560.

Carlborg, P. and Kindström, D. (2014), "Service process modularisation and modular strategies", Journal of Business \& Industrial Marketing, Vol. 29 No. 4, pp. 313-323.

Chandler, J., and Lusch, R.F. (2015), "Service systems: A broadened framework and research agenda on value propositions, engagement and service experience", Journal of Service Research, Vol 18 No. 1, pp. 6-22.

Dubois, A. and Gadde, L.E. (2002), "Systematic combining: An abductive approach to case research", Journal of Business Research, Vol. 55 No. 7, pp. 553-560.

Dubois, A. and Gadde, L.E. (2014), “'Systematic combining' - A decade later”, Journal of Business Research, Vol. 67 No. 6, pp. 1277-1284.

Edvardsson, B., Gustafsson, A. and Roos, I. (2005), "Service portraits in service research: A critical review”, International Journal of Service Industry Management, Vol. 16 No. 1, pp. 107-121.

Eisenhardt, K.M. (1989), "Building theories from case study research", Academy of Management Review, Vol. 14 No. 4, pp. 532-550.

Eisenhardt, K.M. and Graebner, M.E. (2007), "Theory building from cases: Opportunities and challenges", Academy of Management Journal, Vol. 50 No. 1, pp. 25-32.

Eisenmann, T., Parker, G. and Alstyne, M.W.V. (2006), "Strategies for two-sided markets", Harvard Business Review, 84(10), 92-101.

Grubic, T. (2014), "Servitization and remote monitoring technology: A literature review and research agenda", Journal of Manufacturing Technology Management, 25 No.1, pp. 100-124.

Gremyr, I., Löfberg, N. and Witell, L. (2010), "Service innovations in manufacturing firms", Managing Service Quality, Vol. 20 No. 2, pp. 161-175.

Grönroos, C. (2006), “Adopting a service logic for marketing”, Marketing Theory, Vol. 6 No. 3, pp. $317-333$.

Grönroos, C. (2008), "Service logic revisited: Who creates value? And who co-creates?", European Business Review, Vol. 20 No. 4, pp. 298-314.

Grönroos, C. (2011a), "Value co-creation in service logic: A critical analysis", Marketing Theory, Vol. 11 No. 3, pp. 279-301.

Grönroos, C. (2011b), "A service perspective on business relationships: The value creation, interaction and marketing interface", Industrial Marketing Management, Vol. 40 No. 2, pp. 240-247. 
Grönroos, C. and Voima, P. (2013), "Critical service logic: Making sense of value creation and cocreation", Journal of the Academy of Marketing Science, Vol. 41 No. 2, pp. 133-150.

Grönroos, C., and Gummerus, J. (2014), "The service revolution and its marketing implications: service logic vs service-dominant logic”, Managing Service Quality, Vol. 24 No. 3, pp. 206-229.

Jonsson, K., Westergren, U.H. and Holmström, J. (2008), “Technologies for value creation:

An exploration of remote diagnostic systems in the manufacturing industry", Information Systems Journal, Vol. 18 No. 3, pp. 227-245.

Kuschel, J., and Ljungberg, F. (2004) "Decentralized Remote Diagnostics: A Study of Diagnostics in the Marine Industry", Human Computer Interaction, Springer-Verlag London Limited, Leeds, pp. 211226.

Küssel, R., Liestmann, V., Spiess, M. and Stich, V. (2000), "TeleService: A customer-oriented and efficient service?”, Journal of Materials Processing Technology, Vol. 107 No. 1, pp. 363-371.

Laine, T., Paranko, J. and Suomala, P. (2010), "Downstream shift at a machinery manufacturer: The case of the remote technologies", Management Research Review, Vol. 33 No. 10, pp. 980-993.

Lovelock, C., and Gummesson, E. (2004), "Whither services marketing? In search of a new paradigm and fresh perspectives", Journal of Service Research, Vol. 7 No. 1, pp. 20-41.

Lusch, R. F., and Nambisan, S. (2015), "Service Innovation: A Service-Dominant Logic Perspective". Mis Quarterly, Vol. 39 No. 1, pp. 155-175.

Löfberg, N. (2014), Service Orientation in Manufacturing Firms: Understanding Challenges with Service Business Logic, Karlstad University Studies, Karlstad, Sweden.

Mazhelis, O., Warma, H., Leminen, S., Ahokangas, P., Pussinen, P., Rajahonka, M., Siuruainen, R., Okkonen, H., Shveykovskiy, A. and Myllykoski, J. (2013), "Internet-of-things market, value networks, and business models: State of the art report", University of Jyväskylä, Department of Computer Science and Information Systems, Technical Reports TR-39, pp. 13-14.

Mele, C. (2009), "Value innovation in B2B: Learning, creativity, and the provision of solutions within service-dominant logic", Journal of Customer Behavior, Vol. 8 No. 3, pp. 199-220.

Merriam, S.B. (1998), Qualitative Research and Case Study Applications in Education, Jossey-Bass, San Francisco, CA.

Mikkola, J.H. (2007), "Management of product architecture modularity for mass customization: Modeling and theoretical considerations", IEEE Transactions on Engineering Management, Vol. 54 No. 1, pp. 57-69.

Miles, M.B. and Huberman, A.M. (1994), Qualitative Data Analysis, Sage, Thousand Oaks, CA.

Normann, R. and Ramírez, R. (1993), "From value chain to value constellation: Designing interactive strategy", Harvard Business Review, Vol. 71 No. 4, pp. 65-77. 
Oliva, R., and Kallenberg, R. (2003), "Managing the transition from products to services", International Journal of Service Industry Management, Vol. 14 No. 2, pp. 160-172.

Ostrom et al., (2010), "Moving forward and making a difference: Research priorities for the science of service", Journal of Service Research, Vol. 13 No. 1, pp. 4-36.

Payne, A.F., Storbacka, K. and Frow, P. (2008), "Managing the co-creation of value", Journal of the Academy of Marketing Science, Vol. 36 No.1, pp. 83-96.

Pekkarinen, S. and Ulkuniemi, P. (2008), "Modularity in developing business services by platform approach", The International Journal of Logistics Management, Vol. 19 No. 1, pp. 84-103.

Rahikka, E., Ulkuniemi, P. and Pekkarinen, S. (2011), "Developing the value perception of the business customer through service modularity", Journal of Business \& Industrial Marketing, Vol. 26 No. 5, pp. $357-367$.

Ravald, A. and Grönroos, C. (1996), “The value concept and relationship marketing”, European Journal of Marketing, Vol. 30 No. 2, pp. 19-30.

Rust, R.T. and Thompson, D.V. (2006), "How does marketing strategy change in a service-based world?", In Lusch, R.F. and Vargo, S.L., The Service-dominant Logic of Marketing: Dialog, Debate, and Directions, M.E. Sharpe, Armonk, NY, pp. 381-392.

Schumann, J.H., Wünderlich, N.V. and Wangenheim, F. (2012), "Technology mediation in service delivery: A new typology and an agenda for managers and academics", Technovation, Vol. 32 No. 2, pp. 133-143.

Skålén, P., Gummerus, J., von Koskull, C., and Magnusson, P. R. (2015), "Exploring value propositions and service innovation: a service-dominant logic study", Journal of the Academy of Marketing Science, Vol. 43 No. 2, pp. 137-158.

Storbacka, K. and Lehtinen, J.R. (2001), Customer Relationship Management, McGraw-Hill, Singapore.

Vargo, S.L. and Lusch, R.F. (2004), "Evolving to a new dominant logic for marketing”, Journal of Marketing, Vol. 68 No. 1, pp. 1-17.

Vargo, S.L. and Lusch, R.F. (2008a), "Service-dominant logic: Continuing the evolution", Journal of the Academy of Marketing Science, Vol. 36 No. 1, pp. 1-10.

Vargo, S. L., and Lusch, R. F. (2008b), "Why Service?” Journal of the Academy of Marketing Science, Vol. 36 No. 1, pp. 25-38.

Vargo, S.L., Wieland, H., and Akaka, M.A. (2014), "Innovation through institutionalization: A service ecosystems perspective", Industrial Marketing Management, Vol. 44, pp. 63-72. 
Voss, C.A. and Hsuan, J. (2009), "Service architecture and modularity", Decision Sciences, Vol. 40 No 3, pp. 541-569.

Wikström, S. (1996), "Value creation by company-consumer interaction", Journal of Marketing Management, Vol. 12 No. 5, pp. 359-374.

Wünderlich, N.V., Wangenheim, F.V. and Bitner, M.J. (2013), "High tech and high touch: A framework for understanding user attitudes and behaviors related to smart interactive services", Journal of Service Research, Vol. 16 No.1, pp. 3-20.

Yin, R.K. (2003), Case Study Research: Design and Methods, Sage, Thousand Oaks, CA. 



\begin{tabular}{|c|c|c|c|c|c|c|c|}
\hline $\begin{array}{l}\text { Service } \\
\text { process }\end{array}$ & Data transmission & Data analysis & Report to customer & Action plan & Continuous discussions & Customer visit & Follow up \\
\hline Description & $\begin{array}{l}\text { Data are transmitted } \\
\text { automatically from } \\
\text { customer to firm. }\end{array}$ & $\begin{array}{l}\text { Analyses are performed } \\
\text { that include time } \\
\text { compensation and } \\
\text { benchmarking with } \\
\text { installed base at other } \\
\text { customers. }\end{array}$ & $\begin{array}{l}\text { Results from analyses are } \\
\text { reported to the customer, } \\
\text { in writing and/or orally. }\end{array}$ & $\begin{array}{l}\text { Actions to take are } \\
\text { discussed and decided } \\
\text { together with the } \\
\text { customer }\end{array}$ & $\begin{array}{l}\text { Continuous discussions } \\
\text { with customers about } \\
\text { progress, common } \\
\text { work, and emerging } \\
\text { challenges }\end{array}$ & $\begin{array}{l}\text { The firm visits the } \\
\text { customer to build a } \\
\text { deeper relationship, } \\
\text { work on the machine, } \\
\text { and to learn about the } \\
\text { customer's process on } \\
\text { site. }\end{array}$ & $\begin{array}{l}\text { A meeting to follow } \\
\text { up on the actions } \\
\text { taken and to evaluate } \\
\text { improvements in the } \\
\text { customer's process. }\end{array}$ \\
\hline Resources & 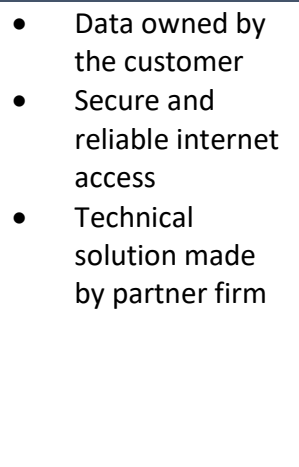 & $\begin{array}{l}\text { - Firm employees with } \\
\text { deep knowledge about } \\
\text { the installed base as } \\
\text { well as analysis } \\
\text { competences } \\
\text { - Software to perform } \\
\text { the analyses } \\
\text { - Data owned by the } \\
\text { customer } \\
\text { - Database of installed } \\
\text { base } \\
\text { - Information }\end{array}$ & $\begin{array}{l}\text { - } \quad \text { Firm employees with } \\
\text { deep knowledge about } \\
\text { the installed base as } \\
\text { well as analysis } \\
\text { competences } \\
\text { - Templates for written } \\
\text { reports } \\
\text { - Information }\end{array}$ & $\begin{array}{l}\text { - Firm and customer } \\
\text { employees with } \\
\text { deep knowledge } \\
\text { about the machine } \\
\text { - Information }\end{array}$ & 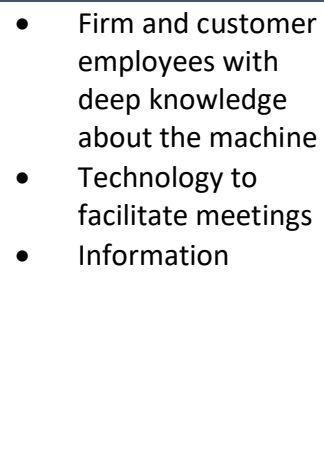 & $\begin{array}{l}\text { - Firm and customer } \\
\text { employees with } \\
\text { deep knowledge } \\
\text { about the machine }\end{array}$ & $\begin{array}{l}\text { - } \quad \text { Firm and } \\
\text { customer } \\
\text { employees with } \\
\text { deep knowledge } \\
\text { about the } \\
\text { machine } \\
\text { - Information }\end{array}$ \\
\hline Integration & $\begin{array}{l}\text { - } \quad \text { Firm access to } \\
\text { customer data }\end{array}$ & $\begin{array}{l}\text { - } \quad \text { No integration } \\
\text { between firm and } \\
\text { customer }\end{array}$ & $\begin{array}{l}\text { Information } \\
\text { transmission from firm } \\
\text { to customer. }\end{array}$ & $\begin{array}{l}\text { Discussions between } \\
\text { firm and customer; } \\
\text { e.g., through video } \\
\text { conferences or } \\
\text { phone calls. }\end{array}$ & $\begin{array}{l}\text { Discussions } \\
\text { between firm and } \\
\text { customer; e.g., } \\
\text { through video } \\
\text { conferences or } \\
\text { phone calls. }\end{array}$ & $\begin{array}{l}\text { Work performance } \\
\text { on machine by } \\
\text { firm employees; } \\
\text { e.g., process } \\
\text { measurements or } \\
\text { trimming } \\
\text { - Job training of } \\
\text { customer } \\
\text { employees }\end{array}$ & $\begin{array}{l}\text { Discussions } \\
\text { between firm } \\
\text { and customer at } \\
\text { customer site }\end{array}$ \\
\hline
\end{tabular}

Table 1: Process modules of a process optimisation service 


\begin{tabular}{|c|c|c|c|c|c|c|c|}
\hline $\begin{array}{l}\text { Service } \\
\text { process }\end{array}$ & Data transmission & $\begin{array}{l}\text { Awareness of abnormal } \\
\text { conditions }\end{array}$ & Report to customer & Action plan & $\begin{array}{l}\text { Maintenance on } \\
\text { customer site }\end{array}$ & Education & Upgrades \\
\hline Resources & 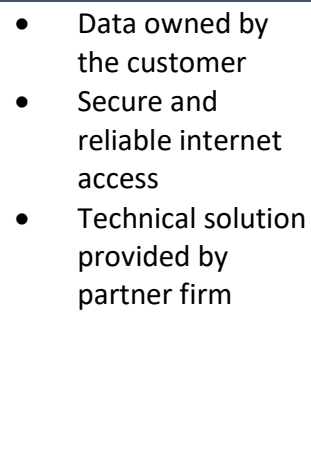 & 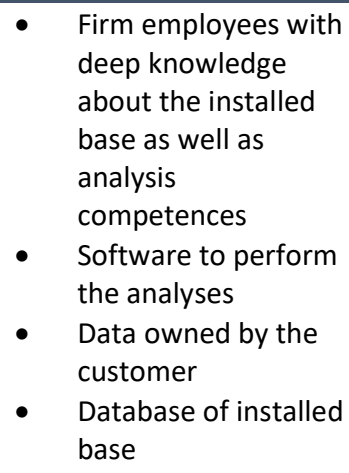 & $\begin{array}{l}\text { - Firm employees with } \\
\text { deep knowledge about } \\
\text { the installed base as } \\
\text { well as analysis } \\
\text { competences } \\
\text { - Templates for written } \\
\text { reports } \\
\text { - Information: } \\
\text { - Performance } \\
\quad \text { report } \\
\text { - Production report }\end{array}$ & 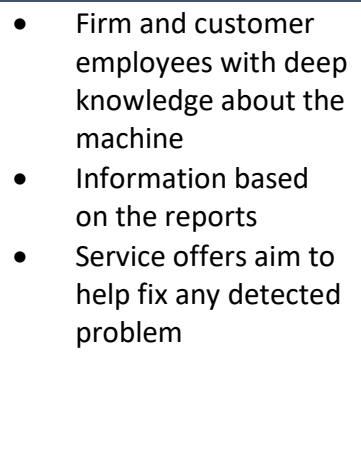 & $\begin{array}{l}\text { - } \quad \text { Firm employees } \\
\text { with deep } \\
\text { knowledge about } \\
\text { the machine } \\
\text { Data from } \\
\text { customer's } \\
\text { machine } \\
\text { Data from } \\
\text { benchmarking } \\
\text { machines }\end{array}$ & $\begin{array}{l}\text { - } \quad \text { Employees, e.g., } \\
\text { operators in } \\
\text { need of training } \\
\text { Data owned by } \\
\text { the firm: } \\
\text { - Downloada } \\
\text { ble training } \\
\text { material } \\
\text { - Downloada } \\
\text { ble } \\
\text { manuals }\end{array}$ & $\begin{array}{l}\text { - } \quad \text { Data owned by } \\
\text { the customer } \\
\text { - } \quad \text { New software } \\
\text { - New parts to } \\
\text { be } \\
\text { interchanged }\end{array}$ \\
\hline Integration & $\begin{array}{l}\text { - } \quad \text { Firm access to } \\
\text { customer data } \\
\text { - } \quad \text { Automatic } \\
\text { inspection }\end{array}$ & 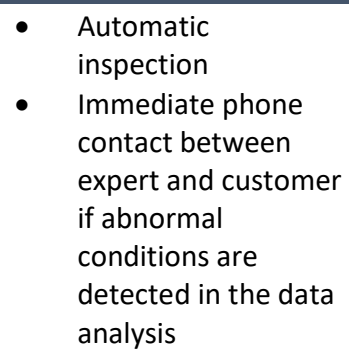 & $\begin{array}{ll}\text { - Information } \\
\text { transmission from firm } \\
\text { to customer } \\
\text { - Written reports }\end{array}$ & $\begin{array}{l}\text { - } \quad \text { Discussions between } \\
\text { firm and customer } \\
\text { - } \quad \text { Manual inspections }\end{array}$ & $\begin{array}{ll}\text { - } & \text { Manual } \\
\text { - } & \text { inspections } \\
\text { Discussions } \\
\text { between firm and } \\
\text { customer } \\
\text { - Work performance } \\
\text { on machine by } \\
\text { firm employees }\end{array}$ & $\begin{array}{l}\text { - Online } \\
\text { integrations } \\
\text { between } \\
\text { customer and } \\
\text { database } \\
\text { Job training of } \\
\text { customer } \\
\text { employees }\end{array}$ & $\begin{array}{ll}\text { - } & \text { Manual and/or } \\
\text { automatic } \\
\text { inspections: } \\
\text { - } \quad \text { Inspection } \\
\quad \text { of HDDs } \\
\text { - } \quad \text { Replacem } \\
\quad \text { ent of } \\
\text { outdated } \\
\text { parts }\end{array}$ \\
\hline
\end{tabular}

Table 2: Process modules of a condition feedback service and a performance feedback service 
Figure 1: A service platform

\section{Service platform}

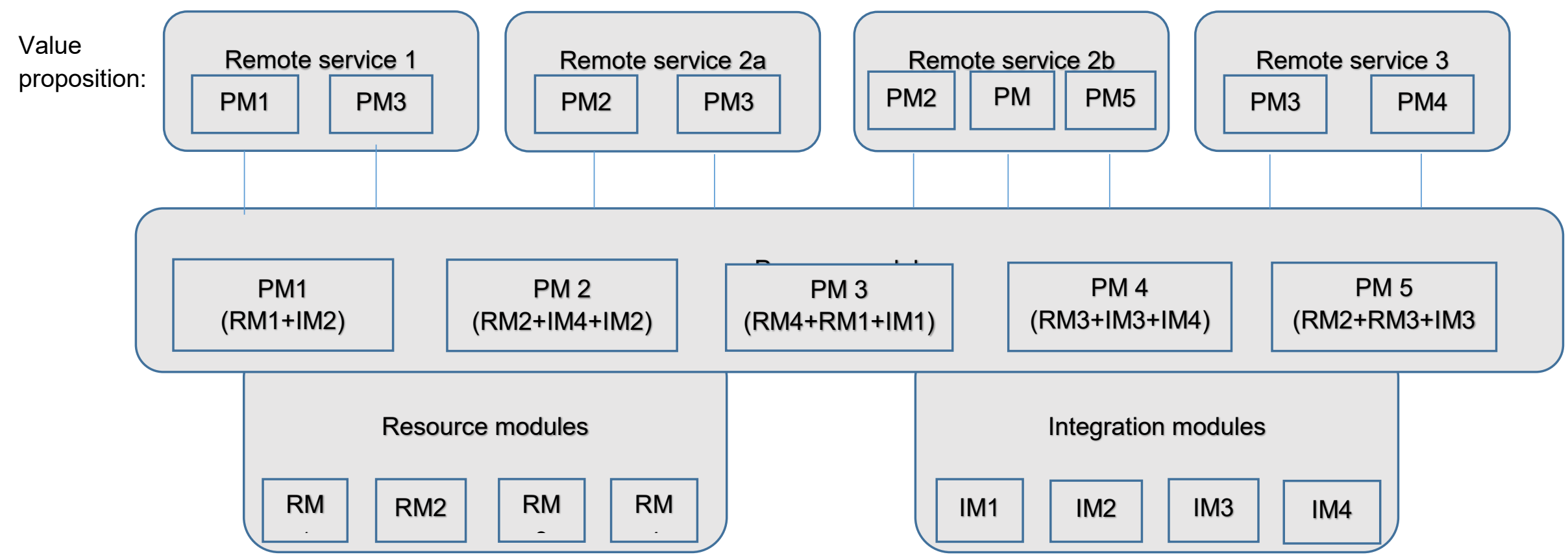

